\title{
The impact of power and relationship commitment on the integration between manufacturers and customers in a supply chain
}

\author{
Xiande Zhao ${ }^{\text {a,* }}$, Baofeng Huo ${ }^{\text {b,1 }}$, Barbara B. Flynn ${ }^{\text {c,2 }}$, Jeff Hoi Yan Yeung ${ }^{\text {a,3 }}$ \\ ${ }^{a}$ Department of Decision Sciences and Managerial Economics, Faculty of Business Administration, \\ The Chinese University of Hong Kong, Shatin, N.T., Hong Kong, China \\ ${ }^{\mathrm{b}}$ School of Management, Xi'an Jiaotong University, Department of Decision Sciences and Managerial Economics, \\ The Chinese University of Hong Kong, Shatin, N.T., Hong Kong, China \\ ${ }^{\mathrm{c}}$ Kelley School of Business, Indiana University, 801 W. Michigan Street, Indianapolis, IN 46202, United States
}

Received 17 November 2006; received in revised form 17 July 2007; accepted 1 August 2007 Available online 19 August 2007

\begin{abstract}
Supply chain integration (SCI) has received increasing attention from scholars and practitioners in recent years. However, our knowledge of what influences SCI is still very limited. Although marketing and management researchers have investigated power and relationship commitment issues between organizations, few have examined their impact on SCI. This paper extends the powerrelationship commitment theory established in Western marketing literature and links it with SCI in China, through examining the relationship between power, relationship commitment and the integration between manufacturers and their customers. We propose and empirically test a model using data collected from 617 manufacturing companies in China. The results show that different types of customer power impact manufacturers' relationship commitment in different ways. Expert power, referent power and reward power are important in improving manufacturers' normative relationship commitment, while reward power and coercive power enhance instrumental relationship commitment. We also found that normative relationship commitment had a greater impact on customer integration than instrumental relationship commitment. These findings are interpreted in light of national culture differences between China and the U.S. in terms of power distance and collectivism, which provide a new perspective on SCI. (C) 2007 Elsevier B.V. All rights reserved.
\end{abstract}

Keywords: Power; Relationship commitment; Supply chain integration; Culture; China

\footnotetext{
* Corresponding author. Tel.: +852 2609 7650; fax: +85226036840 .

E-mail addresses: xiande@baf.msmail.cuhk.edu.hk (X. Zhao), baofeng@baf.msmail.cuhk.edu.hk (B. Huo), bbflynn@iupui.edu (B.B. Flynn), Jeff@baf.msmail.cuhk.edu.hk (J.H.Y. Yeung).

${ }^{1}$ Tel.: +852 2609 8560; fax: +852 26035104 .

${ }^{2}$ Tel.: +1 317278 8586; fax: +1 3172743312 .

${ }^{3}$ Tel.: +852 2609 7779; fax: +852 26036840 .
}

\section{Introduction}

Global competition and escalating customer expectations have led manufacturers to increasingly focus on delivery speed, dependability and flexibility (Boyer and Lewis, 2002; Flynn and Flynn, 2004). To enhance these capabilities, many companies have implemented supply chain integration (SCI) strategies (Bowersox et al., 1999). The literature has cited the importance of SCI in achieving a competitive advantage (Bowersox and Morash, 1989; Lee and Billington, 1992; Morris and 
Calantone, 1991) and enhancing performance (Ahmad and Schroeder, 2001; Frohlich and Westbrook, 2001; Johnson, 1999; Narasimhan and Jayaram, 1998; Stank et al., 2001a; Zhao et al., 2006b). However, our understanding of what enables SCI is still very limited. Although marketing researchers have studied factors that influence inter-firm relationships from the perspective of power and relationship commitment (Morgan and Hunt, 1994; Brown et al., 1995), this perspective has not been applied in a SCI context.

This relationship is of particular interest in China, whose dynamic competitive environment provides fertile ground for investigating power, relationship commitment and their impact on SCI. China has become a very important manufacturing base in the world, with annual GDP growth averaging around $10 \%$ for the last 15 years and the manufacturing component accounts for more than one-third of the total GDP (Zhao et al., 2006a). Because China's national culture is characterized by high power distance and collectivism, it is a particularly interesting location for studying issues related to supply chain (SC) power and relationship commitment.

Transaction cost theory (TCT) provides a useful lens for understanding SCI. TCT was originally introduced by Coase (1937), who examined the make versus buy decision faced by organizations. While producing inhouse may incur higher production costs, buying from the market incurs higher transactions costs. Williamson $(1975,1985,1991,1993,1996)$ proposed four types of transaction costs: (1) search costs, related to gathering information to identify and evaluate potential partners; (2) contracting costs, associated with negotiating and writing an agreement; (3) monitoring costs, associated with ensuring that each party fulfills its obligations; (4) enforcement costs, associated with ex post bargaining and sanctioning of a partner that does not perform according to the agreement. TCT uses the tradeoff between production costs and transaction costs to explain how organizations make make-or-buy decisions.

SCI provides an alternative which lowers the transaction costs normally associated with the "buy" alternative, which is relevant to outsourcing. While production costs are lowered through outsourcing, SCI also reduces transaction costs through building longterm relationships and integrating interorganizational processes. SCI reduces search costs by establishing long-term relationships with fewer suppliers. Because the manufacturer has fewer partners and changes them infrequently, SCI reduces contracting costs by reducing the cost of negotiating and writing contractual agreements. Because manufacturers share information with their customers, the time needed for monitoring compliance with the contract is reduced, reducing monitoring costs. Finally, by jointly formulating strategy and working collaboratively, SCI reduces enforcement costs. Thus, SCI provides a powerful alternative which allows companies to reap the benefits of both "make" and "buy."

In this paper, we investigate the relationship between power, relationship commitment and the integration of manufacturers with their customers, establishing the mechanisms of SCI based on the perspectives of powerrelationship commitment theory, social exchange theory and TCT. Specifically, our objectives are:

1. To identify the antecedents of customer integration and to develop and test an instrument for measuring them in a SC context.

2. To propose and empirically test a model that represents the relationship among customer power, relationship commitment and customer integration in a SC.

3. To justify and develop power-relationship commitment theory in the context of an emerging economy that has a high power distance and collectivist national culture.

4. To offer guidelines for practicing managers to enhance their performance through understanding the role of power in SCI and better management of customer relationships.

\section{Theoretical background and research hypotheses}

We reviewed the multi-disciplinary literature related to power, relationship commitment and customer integration, developing the conceptual framework shown in Fig. 1. In the following sections, we discuss each of its components and develop hypotheses about how they are related.

\subsection{Customer power}

Customer power is the ability of a customer to influence the decisions of a manufacturer in a SC (Brown et al., 1983, 1995; Goodman and Dion, 2001). The more general concept of power has long been an important topic of study in organizational behavior (Drea et al., 1993), with French and Raven's (1959)

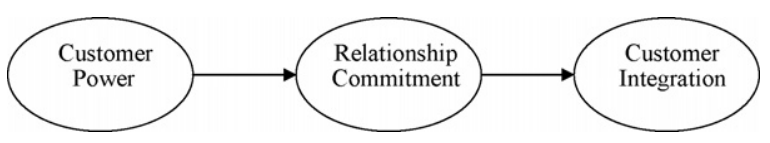

Fig. 1. Conceptual framework. 
Table 1

Bases of inter-firm power

\begin{tabular}{|c|c|c|c|}
\hline Type of power & Power base & Description & Supply chain example \\
\hline \multirow[t]{3}{*}{ Non-mediated } & Expert power & $\begin{array}{l}\text { Customer has knowledge, } \\
\text { expertise or skills desired } \\
\text { by the manufacturer }\end{array}$ & $\begin{array}{l}\text { The customer knows what the final consumer wants or has } \\
\text { knowledge and expertise in designing or distributing new } \\
\text { products to the final consumers }\end{array}$ \\
\hline & Referent power & $\begin{array}{l}\text { Manufacturer values } \\
\text { identification with } \\
\text { the customer }\end{array}$ & $\begin{array}{l}\text { If the customer has developed a strong bond through its } \\
\text { demonstrated concern, management style and organizational } \\
\text { personality, it has power over the manufacturer, based on } \\
\text { positive emotional ties (Goodman and Dion, 2001) }\end{array}$ \\
\hline & Legitimate power & $\begin{array}{l}\text { Manufacturer believes } \\
\text { customer retains natural } \\
\text { right to influence it }\end{array}$ & $\begin{array}{l}\text { The manufacturer believes that the customer has the right to } \\
\text { request and expect things to be done according to its requirements, } \\
\text { as part of the manufacturer-customer relationship. This is a } \\
\text { result of the level of importance accorded the customer } \\
\text { in the supply chain }\end{array}$ \\
\hline \multirow[t]{2}{*}{ Mediated } & Reward power & $\begin{array}{l}\text { Customer has the ability } \\
\text { to mediate rewards to } \\
\text { manufacturer }\end{array}$ & $\begin{array}{l}\text { The customer has the ability to provide rewards that are attractive to } \\
\text { the manufacturer, for example, the customer can decide to give } \\
\text { more business to the manufacturer }\end{array}$ \\
\hline & Coercive power & $\begin{array}{l}\text { Customer has the ability } \\
\text { to mediate punishment } \\
\text { to manufacturer }\end{array}$ & $\begin{array}{l}\text { The customer has the ability to provide punishments that are } \\
\text { detrimental to the manufacturer, for example, the customer can cancel } \\
\text { business or reduce the volume of business with the manufacturer }\end{array}$ \\
\hline
\end{tabular}

Adapted from Maloni and Benton (2000, p. 54).

seminal work classifying power into five sources holding up to extensive empirical testing for almost 50 years (Rabin et al., 2001). Table 1 provides a definition and SC example of each of the sources of power. While some function as a "carrot," attracting manufacturers without the customer taking any explicit action, others function as a "stick" wielded by customers to ensure manufacturer compliance. These are known as non-mediated and mediated sources of power, respectively (Tedeschi et al., 1972).

Reward and coercive power are considered mediated because their use is controlled by the customer, which can reward a manufacturer by creating positive consequences, such as placing customer orders (Rezaboklah et al., 2006), or coerce it through negative consequences, such as canceling an order. The customer, as the source of the power, decides whether, when and how to use its power to influence the manufacturer's behavior. In contrast, expert, referent and legitimate power are considered non-mediated, because the manufacturer, itself, decides whether and how much it will be influenced by a customer. The manufacturer seeks association with a customer because of its perception of the customer's knowledge or expertise (expert power), reputation (referent power) or its belief that the customer has the natural right to influence it (legitimate power).

National culture may play an important role in SC power. In a high power distance national culture like China, there is an acceptance of power inequalities (Hofstede, 1980, 1991; Wang and Clegg, 2002). In fact, people expect decisions to be made by the more powerful party and may not feel comfortable otherwise (Randolph and Sashkin, 2002). Because non-mediated power is based on the perception of the source's power, rather than on its exercise, we expect that expert, referent and legitimate power will be strong in China's high power distance national culture, where perceived differences in power are taken very seriously. In addition, members of high power distance national cultures are more willing to accept the use of coercive and reward power (Wang and Clegg, 2002). Because the use of power needs less legitimization in a high power distance national culture (Hofstede et al., 2002), it is reasonable to believe that the effects of both mediated and non-mediated sources of power will be stronger in China than in Western societies.

Guanxi, which is a behavioral outgrowth of China's cultural values, is the granting of preferential treatment to business partners, in exchange for favors and obligations (Lee et al., 2001). It is a morally binding social norm that a favor should be reciprocated as soon as the opportunity arises (Lee and Dawes, 2005). Not returning a favor results in loss of face for both the manager and his in-group. Because guanxi is based on the expectation of reciprocity, we expect that reward power will be particularly strong in China.

\subsection{Relationship commitment}

Relationship commitment is the willingness of a party to invest financial, physical or relationship-based 
resources in a relationship (Morgan and Hunt, 1994). In a SC, it is an attitude of SC partners about the development and maintenance of a stable, long-lasting mutual relationship (Anderson and Weitz, 1992; Moore, 1998). From the perspective of TCT, relationship commitment can be viewed as an investment in transaction-specific assets, which are difficult or impossible to redeploy when a relationship is terminated (Heide, 1994; Joshi and Stump, 1999). For example, relocation of a manufacturer's facility to be in physical proximity of a customer is an investment in a transaction-specific asset because it cannot be redeployed to a different customer if the original relationship is terminated. Other examples of transaction-specific assets include customer-specific training of a manufacturer's personnel, modification of internal manufacturing processes to accommodate a specific customer's product, exchange of personnel, direct capital investments (Carr and Pearson, 1999), and information systems, such as networks, quick ordering systems and point of sale systems for leading customers.

Relationship commitment can be classified as normative or instrumental (Brown et al., 1995). Normative relationship commitment is a mutual, ongoing relationship over an extended period of time which is based on mutual commitment and sharing (Ellram, 1991). At the heart of normative relationship commitment is trust (LaLonde and Cooper, 1989), which is the belief that a partner will not act opportunistically (Anderson and Narus, 1990). Instrumental relationship commitment, in contrast, is based on compliance (Brown et al., 1995). Compliance occurs when one party accepts the influence of another in hopes of receiving favorable reactions from the other party.

Because TCT underestimates the role of social interactions, such as relationship commitment (Ghoshal and Moran, 1996; Granovetter, 1985; Hill, 1990; Atuahene-Gima and $\mathrm{Li}, 2002$ ), we call upon social exchange theory, which is driven by the central concept of exchanging resources via a relationship exchange. It suggests that the behavior of a company in a transaction cannot be explained solely by economic factors, but should also be explained by social factors including repeated exchanges, future obligations and the belief that each party will fulfill its obligations (Blau, 1964; Thibaut and Kelley, 1959). This is particularly relevant in China's collectivist national culture, where guanxi creates obligations in business relationships. From the perspective of social exchange theory, power, trust and relationship commitment play an important role in SC relationships.

\subsubsection{Relationship between customer power and normative relationship commitment}

Relationship commitment is built upon the construct of loyalty, which is a propensity to transact, resulting in sequential purchase or proportionality (Fournier, 1998). Rather than increasing the extent of hierarchical control to protect transaction-specific assets from opportunistic appropriation, SC partners in a committed relationship engage in relational governance, including investment in transaction-specific assets and a high level of organizational trust. Thus, the motive for exchange relationships departs from purely economic and is overlaid with a social context that carries strong expectations of trust and the absence of opportunism (Zaheer and Venkataraman, 1995).

China's cultural collectivism lays the foundation for normative relationship commitment, where group interests dominate. In fact, the Chinese tradition has no equivalent to the Western concept of self as a separate entity, distinct from society and culture (Etzioni, 1975). Members of collective cultures readily subordinate their personal goals to those of the group (Hofstede, 1980, 1991; Briley and Wyer, 2002) and place the interests of the collective above their own (Chow et al., 2000). The essence of a collective culture is a constant concern for belongingness, dependency and reciprocity (Griffith et al., 2006). Thus, normative relationship commitment may be easier to develop in China, since members of its highly collective culture experience relatedness with others as a fundamental part of themselves (Eaton and Louw, 2000). The perception of non-mediated power sources enhances attitudes towards SC relationships, fostering congruence in values and norms between members (Frazier and Summers, 1986). Jonsson and Ziveldin (2003) found that non-mediated sources of power increased the value of a relationship by increasing the level of effective cooperation, consistent with the notion of normative relationship commitment.

Expert power in a SC is commitment to customers that possess knowledge, skills or expertise that they believe will be beneficial to them (French and Raven, 1959). For example, by providing its suppliers with Six Sigma training and helping them get started with their own projects, manufacturers learn valuable skills from Cummins Engine. Therefore, we hypothesize:

H1a. A manufacturer's normative relationship commitment will be positively related to its perception of the expert power of its customer.

Referent power is related to an organization's identification with and internalization of the goals 
and values of the other party (Morgan and Hunt, 1994; Wetzels et al., 1998). Identification occurs when a manufacturer accepts a customer's influence because it admires the way the customer manages its business and wants to establish a relationship with it. For example, many manufacturers proudly display plaques indicating that they are preferred suppliers to leading companies. Internalization occurs when a manufacturer accepts a customer's influence because it holds values and norms of behavior that are similar (Brown et al., 1995). Identification and internalization may be especially potent in China, where power is transferred through the extended guanxi network (Zhuang and Zhou, 2004). Therefore,

H1b. A manufacturer's normative relationship commitment will be positively related to its perception of the referent power of its customer.

When a manufacturer believes that its customer has the legitimate right to influence it and that it is obligated to accept that influence (Rezaboklah et al., 2006), the manufacturer has legitimized the customer's influence. Because of its perception of legitimate power, the manufacturer does not question actions taken by the customer, it simply complies. For example, state-owned manufacturing enterprises in China were historically provided with production schedules by the central government. Despite the fact that these production schedules were frequently out of synch with market demand, they were not questioned, because the central government was believed to have the natural right to determine the policies and practices of state-owned enterprises. Thus, we propose:

H1c. A manufacturer's normative relationship commitment will be positively related to its perception of the legitimate power of its customer.

Empirical findings on the relationship between nonmediated sources of power and normative relationship commitment are somewhat mixed in Western-based research. Geyskens et al. (1999) found that noncoercive influence strategies had an indirect positive effect on commitment, while Brown et al. (1995) reported that manufacturers' non-mediated sources of power had a direct effect on retailers' normative relationship commitment. While Maloni and Benton (2000) and Benton and Maloni (2005) found a positive relationship between both expert and referent power and normative relationship commitment, legitimate power was found to be negatively related. Wu et al. (2004) found a positive relationship between power and normative relationship commitment.
Mediated sources of power are inconsistent with normative relationship commitment because they are manipulative by nature. Customers' exercise of reward power manipulates the manufacturer through the provision of rewards for desired behaviors (Rezaboklah et al., 2006), which flies in the face of the trust that is at the heart of normative relationship commitment. The frequent use of mediated power has been shown to damage relational norms (Skinner et al., 1992), reducing the strength of a relationship (Benton and Maloni, 2005; Maloni and Benton, 2000). Referring to normative relationship commitment, Brown et al. (1995) stated, "As these intrinsic factors become central, extrinsic factors such as rewards and punishments, become less important (p. 368)." Therefore, we expect that the customer's use of reward power will decrease normative relationship commitment. Thus,

H1d. A manufacturer's normative relationship commitment will be negatively related to its perception of the reward power of its customer.

Similarly, coercive power is exhibited through customers' threats to withdraw business unless the manufacturer engages in desired behaviors, such as price concessions or quality improvement. For example, Ford routinely delayed sending payments that were owed for engines supplied by Navistar, using what it believed to be its coercive power, in order to force Navistar to extend longer payment terms. In an interesting turn of events, however, Navistar shut down its factories and stopped producing Ford engines, shifting the coercive power from the customer to the manufacturer. The situation eventually had to be settled by a court order, illustrating a clear lack of normative relationship commitment between Ford and Navistar.

Coercive power exists when the powerful party uses its resources to harm its SC partner (Kumar et al., 1995, 1998). This is consistent with TCT's assumption that the risk of opportunism is inherent in many transactions. Opportunism is defined as:

"self-interest seeking with guile. This includes but is scarcely limited to more blatant forms, such as lying, stealing, and cheating. More generally, opportunism refers to the incomplete or distorted disclosure of information, especially to calculated efforts to mislead, distort, disguise, obfuscate, or otherwise confuse" (Williamson, 1985, p. 47).

Because SCI requires a manufacturer to invest specific assets in a relationship, there is the potential for opportunistic behaviors by its customers (Jap and Ganesan, 2000; Gundlach et al., 1995). This can 
increase transaction costs, as the manufacturer employs governance mechanisms to safeguard against opportunism (Williamson, 1985). Opportunism leads to deterioration in trust and relationship commitment. For example, a company can send an unmistakable signal about its readiness to use its capability to potentially bury a manufacturer with litigation by simply accumulating potentially damaging legal resources. The perspective of resource dependence theory (Pfeffer and Salancik, 1978) suggests that asymmetric power relationships between customers and manufacturers are inherently unstable (Lawler, 1986; Rubin and Brown, 1975). The less dependent firm has little to lose, little fear of retaliation and few restraints on its punitive actions. Thus, the manufacturer's expectation of coercion grows as the customer's punitive capability increases (Lawler et al., 1988). Clearly, the use of coercive power is counter to normative relationship commitment's goal of establishing a satisfying relationship between SC members.

H1e. A manufacturer's normative relationship commitment will be negatively related to its perception of the coercive power of its customer.

Empirical findings on the relationship between mediated power and normative relationship commitment are quite inconsistent. Although Brown et al. (1995) and Maloni and Benton (2000) found that mediated sources of power were negatively related to normative relationship commitment, Jonsson and Ziveldin (2003) found that coercive power was nonsignificant. Ramaseshan et al. (2006) found that both coercive power and reward power had a positive effect on commitment, and Maloni and Benton likewise found a positive relationship between reward power and normative relationship commitment. Wong et al. (2005), however, found that Chinese managers avoided opportunistic behavior because of the value placed on interpersonal relationships. Thus, there is a need for further testing of this relationship.

\subsubsection{Relationship between customer power and instrumental relationship commitment}

Because instrumental relationship commitment is based on calculation of benefits and costs (Brown et al., 1995) and manipulation, it is expected that expert, referent and legitimate power will be inversely related to it. The use of non-mediated sources of power fosters congruence in values and norms of behavior because the manufacturer willingly accepts the customer's influence. This then decreases its tendency to make commitments based on calculation of short-term financial benefits and costs.

H2a. A manufacturer's instrumental relationship commitment will be negatively related to its perception of the expert power of its customer.

H2b. A manufacturer's instrumental relationship commitment will be negatively related to its perception of the referent power of its customer.

H2c. A manufacturer's instrumental relationship commitment will be negatively related to its perception of the legitimate power of its customer.

Because a customer's reward or coercive power provides extrinsic motivation for commitment (Brown et al., 1995), we hypothesize that mediated sources of power will be positively related to instrumental relationship commitment. This relationship may be especially potent in China, because of the importance of guanxi, whose rewards can include access to limited resources and controlled information, preferential terms for pricing, contracts and credit, and protection from external competitors (Lee et al., 2001). Because of the obligation to exchange favors with other members of the network (Leung et al., 2005), Chinese manufacturers place substantial weight on the anticipated reaction of customers. For example, if a purchasing manager places an order with a member of his guanxi network, the supplying manager is obligated to respond with a gift, favor or concession. If the obligation is not fulfilled within a short amount of time, the guanxi relationship will become strained and the social harmony between the managers disturbed, because the supplying manager has lost face (Lee et al., 2001). Guanxi relationships are viewed as more reliable than a written contract (legitimate power) in China (Leung et al., 2005), because the unreliable Chinese legal system historically made it difficult to uphold contracts (Wong et al., 2005), and because of the perception that contracts are used primarily by foreigners to take advantage of Chinese organizations. This is consistent with the work of Pearce (2001a,b) and Rao et al. (2005) on facilitative governments, which states that, in the presence of a nonsupportive or erratic government, personal relationships emerge as the most important form of governance. Therefore, we expect that the use of reward power will foster stronger instrumental relationship commitment (Brown et al., 1995; Kasulis and Spekman, 1980).

H2d. A manufacturer's instrumental relationship commitment will be positively related to its perception of the reward power of its customer. 
Customers may use coercive power to pressure a manufacturer to comply with their requirements, thereby increasing the manufacturer's instrumental relationship commitment, and guanxi is related to coercive power. If there is no guanxi between SC partners, there is no obligation (Lee and Dawes, 2005). In fact, Lee et al. (2001) describe a type of guanxi known as instrumental guanxi, manifest in temporary, impersonal ties that are based on transactional relationships. They may be of short duration; when the need ceases to exist, so does the guanxi. In a relationship without guanxi, Chinese managers will readily exploit their partners (Wong et al., 2005). The pervasiveness of guanxi makes the use of coercive power seem natural in China. Therefore,

H2e. A manufacturer's instrumental relationship commitment will be positively related to its perception of the coercive power of its customer.

\subsection{Customer integration}

Our discussion of customer integration (CI) begins with the broader construct of SCI. SCI is the degree to which an organization strategically collaborates with its SC partners and manages intra- and inter-organization processes to achieve effective and efficient flows of products, services, information, money and decisions, with the objective of providing maximum value to its customers (Bowersox et al., 1999; Frohlich and Westbrook, 2001; Naylor et al., 1999). This involves information sharing, planning, coordinating and controlling materials, parts and finished goods at the strategic, tactical and operational levels (Stevens, 1989). Benefits arise from managing a SC as a single system, as opposed to individually optimizing fragmented subsystems (Watts and Hahn, 1993; Watts et al., 1995; Vickery et al., 2003).

Though there is not a commonly agreed framework for the components of SCI, two primary factors have been investigated: specific investments and relationship governance. SCI-specific investments include information systems, dedicated employees and other assets invested in SCI (Power, 2005; Narasimhan and Kim, 2001; Stank et al., 2001a,b; Frohlich and Westbrook, 2001; Zhao et al., 2006b). Examples of SCI relationship governance include information sharing, strategic partnerships, collaboration and other approaches for managing and controlling SCI relationships (Power, 2005; Armistead and Mapes, 1993; Morash and Clinton, 1998; Stank et al., 2001a,b; Johnson, 1999; Frohlich and Westbrook, 2001; Zhao et al., 2006b).
There are numerous types of SCI, including strategic, internal, customer, supplier, information, planning, measurement and relationship integration (Stank et al., 2001a), however, there is a great deal of overlap between these constructs. Customer integration (CI) has been found to be the most important type of SCI in influencing competitive performance (Stank et al., 2001a; Zhao et al., 2006b), thus, we focus on it in this study. CI derives from coordination with critical SC customers (Bowersox et al., 1999). Information sharing, coordination and synchronization of processes are critical activities in CI.

\subsubsection{Relationship between normative relationship commitment and customer integration}

Because CI is built upon SC partnerships (Wisner and Tan, 2000), relationship commitment plays an important role, however, few studies have investigated the impact of relationship commitment on $\mathrm{CI}$ from the perspective of SCM. In addition, much of the prior research fails to differentiate between normative relationship commitment and instrumental relationship commitment. For example, Morgan and Hunt (1994) found that relationship commitment positively influenced acquiescence and cooperation and negatively influenced propensity to leave, but they did not separate the effects of normative and instrumental relationship commitment. Chen and Paulraj (2004) similarly refer to a broad relationship commitment construct, stating that SC members integrate with their key customers' business processes and goals when there is relationship commitment.

TCT and social exchange theory provide an explanation of the mechanisms of normative and instrumental relationship commitment in improving CI. Normative relationship commitment leads to stable long-term relationships, in which opportunistic behaviors are reduced because they contradict the interests of the other party (Williamson, 1985). To reduce transaction costs and opportunistic behaviors, SC partners develop and enhance normative relationship commitment, where both partners are willing to communicate and to share information. From the perspective of social exchange theory, trust is critical, because it develops from shared values, which improves communication and understanding between SC partners (Atuahene-Gima and $\mathrm{Li}$, 2002), and trust may prevail even where opportunism might be rationally expected (Atuahene-Gima and $\mathrm{Li}$, 2002), because social exchange theory allows for trustworthy behaviors even if explicit controls against opportunism are not in place (Granovetter, 1985). Trust improves commitment, because it reduces the risk or opportunistic behavior and thus increases SC partners' confidence in the effectiveness of future exchanges and 
motivates them to commit to the relationship (Moore, 1998; Ruyter et al., 2001).

Normative relationship commitment reflects the manufacturer's willingness to maintain a long-term relationship with its customer through affective attachment and the identification of and internalization with the values and norms of the customer. This committed long-term relationship is based on an orientation toward repeated transactions and shared values that ensure future obligation and reduce intention to leave. Thus, manufacturers with greater normative relationship commitment are more likely to integrate with their customers. Thus, we hypothesize:

H3a. The degree of integration between a manufacturer and its customer will be positively related to the manufacturer's normative relationship commitment.

\subsubsection{Relationship between instrumental}

\section{relationship commitment and customer integration}

There is very little literature on the role of instrumental relationship commitment in CI. Companies with instrumental relationship commitment will likely commit to a relationship only when they can be rewarded. Instrumental relationship commitment is not based on shared norms or values, nor is it long-term oriented. Furthermore, instrumental relationship commitment may lead to opportunistic behavior, since calculation is the major driver for commitment to a SC relationship. We propose the following hypothesis:
H3b. The degree of integration between a manufacturer and its customer will be positively related to the manufacturer's instrumental relationship commitment.

Hess and Story (2005) describe normative relationship commitment as the ultimate relationship disposition; although it takes longer to develop than a transactional relationship, its benefits are more enduring. When SC members cooperate to maintain a relationship because they believe it is important enough to warrant the effort, they may be willing to sacrifice short term benefits, in order to achieve long term gains (Dwyer et al., 1987; LaLonde and Cooper, 1989). Thus, normative relationship commitment is stronger than instrumental relationship commitment, which is transactional, rather than relationship based.

H3c. Normative relationship commitment by the manufacturer will have a stronger impact on customer integration than instrumental relationship commitment.

An overview of the proposed hypotheses and their inter-relationship is provided in Fig. 2.

\section{Research methodology}

\subsection{Sampling and data collection}

Since China is very large with uneven economic development across regions (Zhao et al., 2006a), we strategically selected five cities to provide geographic

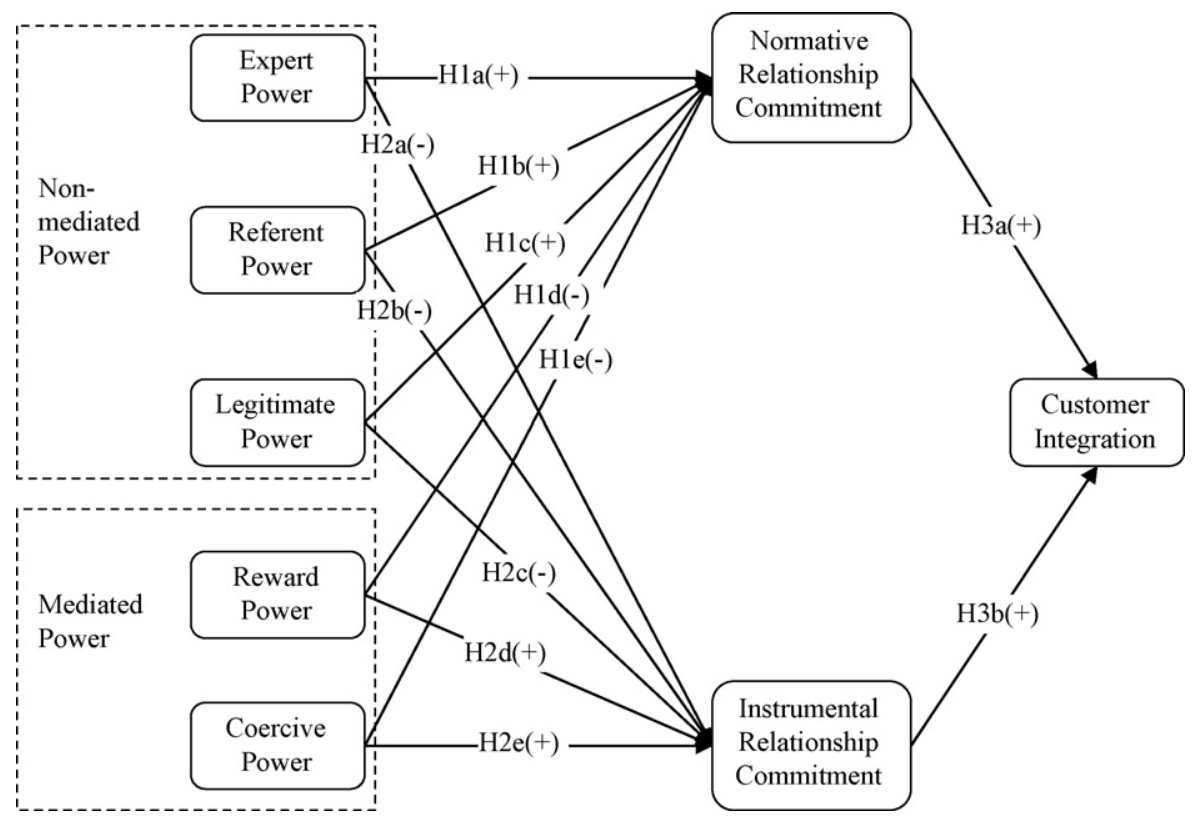

Fig. 2. Proposed model. 
and economic diversity. All are important industrial cities with a broad variety of manufacturing activities. Shanghai represents the Yangtze River Delta, which has China's highest GDP per capita. Guang Zhou represents the Pearl River Delta, which has China's second highest GDP per capita. Both are located in eastern and southern China, which has the highest degree of marketization and economic reform. Tianjin represents the Bohai Sea Economic area and reflects an average level of economic reform and marketization. Chongqing, located in the southwest, represents a relatively lower stage of economic reform and marketization. We also included Hong Kong. Although most Hong Kong companies have their manufacturing facilities in Mainland China, they operate in quite a different environment.

To obtain a representative sample, we randomly selected companies from the yellow pages of China Telecom for the four mainland cities and from the directory of the Chinese Manufacturers Association for Hong Kong. Research assistants called randomly selected companies to determine the contact information for key informants, who were SC managers, CEOs/presidents, vice presidents in charge of marketing and sales managers. We sent the questionnaire to the key informant, along with a cover letter highlighting the study's objectives. Respondents were encouraged to participate by entitlement to a summary report and a small incentive gift. Self-addressed, stamped envelopes were included, and follow-up calls were made to improve the response rate. Out of the 4569 companies contacted, a total of 1356 agreed to receive the questionnaire. After several follow-up calls, 617 usable questionnaires were received. The response rate, based on the number of companies contacted, was $13.5 \%$, however, it was $45.5 \%$ based on the number of questionnaires distributed.

\subsection{Questionnaire design}

We undertook an intensive study of the literature to identify existing measures for related constructs. For constructs which had not been well documented and tested in the literature, we developed new items based on our understanding of the constructs, observations during company visits and interviews with practitioners. The measures for expert, referent, legitimate, reward and coercive power were adapted from Brown et al. (1995). We used a subset of their legitimate power items, selecting those related to the natural right of a customer to influence a manufacturer. We did not include their items designed to measure power based on judicial or legal right, because our interviews revealed that it was not a big concern for respondents, since regulations for economic activities are not well formed. Respondents were asked to indicate the extent of their agreement with statements concerning the use of power by their primary customer, using a Likert scale where " 1 " indicates "strongly disagree" and " 7 " indicates "strongly agree." The measures for normative and instrumental relationship commitment were also adopted from Brown et al. (1995). The measures for customer integration were selected from those used by Narasimhan and Kim (2002) and Frohlich and Westbrook (2001).

The questionnaire was written in English, then translated into Chinese by an operations management professor in China. It was then back-translated into English by a different operations management professor in Hong Kong and the translation checked against the original English version for accuracy. The Chinese version was used in Mainland China, while a bilingual version was used in Hong Kong. The questionnaire was pilot tested in a sample of fifteen companies, where we conducted face-to-face discussions with executives after they completed the questionnaire. Based on their feedback, we modified, added or deleted questions, making them more understandable and relevant to practices in China.

Since we used a single informant to answer all questions, we checked for common method bias. The items comprising the power, relationship commitment and customer integration scales were not highly similar in content, and the respondents were familiar with the constructs. Harman's one-factor test of common method bias (Hochwarter et al., 2004; Podsakoff and Organ, 1986; Podsakoff et al., 2003) found several distinct factors for all variables, revealing that common method variance bias was not a problem.

\section{Analysis and results}

\subsection{Respondent profiles}

The responding companies represent a number of industries, as illustrated in Table 2. Three quarters of the respondents had been in their position for more than 3 years. Thus, the respondents were familiar with their companies' activities, and the data collected from them should be reliable. Table 3 contains basic information about the customers. We defined "primary customer" as the customer purchasing the highest dollar volume from the manufacturer. The mean number of customers per manufacturer was 177 , and half the manufacturers 
Table 2

Company profiles

\begin{tabular}{|c|c|c|c|c|c|c|}
\hline Industry & $\begin{array}{l}\text { Total } \\
(n=617)\end{array}$ & $\begin{array}{l}\text { Hong Kong } \\
(n=206)\end{array}$ & $\begin{array}{l}\text { Guangzhou } \\
(n=104)\end{array}$ & $\begin{array}{l}\text { Chongqing } \\
(n=104)\end{array}$ & $\begin{array}{l}\text { Shanghai } \\
(n=100)\end{array}$ & $\begin{array}{l}\text { Tianjin } \\
(n=103)\end{array}$ \\
\hline $\begin{array}{l}\text { Food, beverage, alcohol } \\
\text { and cigars }\end{array}$ & $30(4.87 \%)$ & $12(5.85 \%)$ & $6(5.77 \%)$ & $5(4.81 \%)$ & $1(1.00 \%)$ & $6(5.83 \%)$ \\
\hline Chemicals and petrochemicals & $39(6.33 \%)$ & $3(1.46 \%)$ & $9(8.65 \%)$ & $8(7.69 \%)$ & $8(8.00 \%)$ & $11(10.68 \%)$ \\
\hline Wood and furniture & $12(1.95 \%)$ & $2(0.98 \%)$ & $4(3.85 \%)$ & $2(1.92 \%)$ & $0(0.00 \%)$ & $4(3.88 \%)$ \\
\hline Pharmaceutical and medical & $11(1.79 \%)$ & $5(2.44 \%)$ & $0(0.00 \%)$ & $4(3.85 \%)$ & $0(0.00 \%)$ & $2(1.94 \%)$ \\
\hline Building materials & $31(5.03 \%)$ & $4(1.95 \%)$ & $7(6.73 \%)$ & $9(8.65 \%)$ & $7(7.00 \%)$ & $4(3.88 \%)$ \\
\hline Rubber and plastics & $41(6.66 \%)$ & $19(9.27 \%)$ & $3(2.88 \%)$ & $3(2.88 \%)$ & $8(8.00 \%)$ & $8(7.77 \%)$ \\
\hline $\begin{array}{l}\text { Metal, mechanical and } \\
\text { engineering }\end{array}$ & $157(25.49 \%)$ & $19(9.27 \%)$ & $30(28.85 \%)$ & $37(35.58 \%)$ & $42(42.00 \%)$ & $29(28.16 \%)$ \\
\hline Electronics and electrical & $81(13.15 \%)$ & $28(13.66 \%)$ & $10(9.62 \%)$ & $12(11.54 \%)$ & $11(11.00 \%)$ & $20(19.42 \%)$ \\
\hline Textiles and apparel & $110(17.86 \%)$ & $73(35.61 \%)$ & $15(14.42 \%)$ & $4(3.85 \%)$ & $10(10.00 \%)$ & $8(7.77 \%)$ \\
\hline Toys & $8(1.30 \%)$ & $8(3.90 \%)$ & $0(0.00 \%)$ & $0(0.00 \%)$ & $0(0.00 \%)$ & $0(0.00 \%)$ \\
\hline Jewelry & $3(0.49 \%)$ & $2(0.98 \%)$ & $0(0.00 \%)$ & $0(0.00 \%)$ & $0(0.00 \%)$ & $1(0.97 \%)$ \\
\hline Arts and crafts & $12(1.95 \%)$ & $1(0.49 \%)$ & $4(3.85 \%)$ & $5(4.81 \%)$ & $1(1.00 \%)$ & $1(0.97 \%)$ \\
\hline Publishing and printing & $27(4.38 \%)$ & $5(2.44 \%)$ & $2(1.92 \%)$ & $10(9.62 \%)$ & $7(7.00 \%)$ & $3(2.91 \%)$ \\
\hline Sales & $\begin{array}{l}\text { Total } \\
(n=587)\end{array}$ & $\begin{array}{l}\text { Hong Kong } \\
(n=176)\end{array}$ & $\begin{array}{l}\text { Guangzhou } \\
(n=104)\end{array}$ & $\begin{array}{l}\text { Chongqing } \\
(n=104)\end{array}$ & $\begin{array}{l}\text { Shanghai } \\
(n=100)\end{array}$ & $\begin{array}{l}\text { Tianjin } \\
(n=103)\end{array}$ \\
\hline$<\mathrm{HK} \$ 5 \mathrm{~m}$ & $190(32.37 \%)$ & $16(9.09 \%)$ & $51(49.04 \%)$ & $35(33.65 \%)$ & $30(30.00 \%)$ & $58(56.31 \%)$ \\
\hline $\mathrm{HK} \$ 5 \mathrm{~m}$ to $<\$ 10 \mathrm{~m}$ & $83(14.14 \%)$ & $16(9.09 \%)$ & $19(18.27 \%)$ & $13(12.50 \%)$ & $16(16.00 \%)$ & $19(18.45 \%)$ \\
\hline $\mathrm{HK} \$ 10 \mathrm{~m}$ to $<\$ 20 \mathrm{~m}$ & $73(12.44 \%)$ & $27(15.34 \%)$ & $5(4.81 \%)$ & $20(19.23 \%)$ & $12(12.00 \%)$ & $9(8.74 \%)$ \\
\hline $\mathrm{HK} \$ 20 \mathrm{~m}$ to $<\$ 50 \mathrm{~m}$ & $93(15.84 \%)$ & $39(22.16 \%)$ & $13(12.50 \%)$ & $17(16.35 \%)$ & $15(15.00 \%)$ & $9(8.74 \%)$ \\
\hline $\mathrm{HK} \$ 50 \mathrm{~m}$ to $<\$ 100 \mathrm{~m}$ & $60(10.22 \%)$ & $24(13.64 \%)$ & $10(9.62 \%)$ & $8(7.69 \%)$ & $15(15.00 \%)$ & $3(2.91 \%)$ \\
\hline HK $\$ 100 \mathrm{~m}$ or more & $88(14.99 \%)$ & $54(30.68 \%)$ & $6(5.77 \%)$ & $11(10.58 \%)$ & $12(12.00 \%)$ & $5(4.85 \%)$ \\
\hline
\end{tabular}

had fewer than 40 customers. This suggests that these manufacturers primarily served business customers, not final consumers. For half of the manufacturers, the primary customer contributed at least $50 \%$ of their sales. Thus, the primary customers are large. The mean number of years the average manufacturer has been doing business with its primary customer was 10.7. This reveals that the relationship between the manufacturer and its primary customer is long-term and stable, making it appropriate for studying normative and

Table 3

Basic information about customers

\begin{tabular}{lccc}
\hline & $\begin{array}{l}\text { Number of } \\
\text { customers }\end{array}$ & $\begin{array}{c}\text { Percentage of sales to } \\
\text { primary customer (\%) }\end{array}$ & $\begin{array}{c}\text { Length of relationship with } \\
\text { primary customer (years) }\end{array}$ \\
\hline Mean & 176.79 & 50 & 10.66 \\
Median & 40.00 & 50 & 10.00 \\
S.D. & 506.267 & 25.6 & 7.950 \\
Minimum & 1.00 & 2 & 1.00 \\
Maximum & 7000.00 & 100 & 65.00 \\
Percentiles & & & 3.00 \\
10 & 6.00 & 15 & 5.00 \\
25 & 15.00 & 30 & 10.00 \\
50 & 40.00 & 50 & 15.00 \\
75 & 120.00 & 70 & 20.00 \\
90 & 500.00 & 80 & 25.00 \\
95 & 1000.00 & 90 & 10.97 \\
Metal, mechanical and engineering & 154.45 & 52 & 9.60 \\
Electronics and electrical & 233.21 & 51 & 11.64 \\
Textiles and apparel & 92.20 & 50 & 10.41 \\
Other industries & 206.79 & 50 & 0.327 \\
Significance level & 0.176 & 0.859 & \\
\hline
\end{tabular}


instrumental relationship commitment. ANOVA revealed no significant differences in the number of customers, percent of sales to the primary customer or relationship length across the industries, thus, it is appropriate to analyze these relationships at the aggregate level.

Since power and relationship commitment may evolve with increasing relationship length, we also tested the correlation between relationship length, dimensions of power and types of relationship commitment. The correlation between relationship length, type of relationship commitment and referent, reward or coercive power was not significant. The correlations between relationship length and expert and legitimate power were quite low, although they were statistically significant. Thus, sample bias due to the length of the relationship is not a problem. Furthermore, we found that number of customers and the primary customer's contribution to the manufacturer's sales were not related to any of the dimensions of power or relationship commitment. These findings further justify the stability and robustness of the power and relationship commitment constructs. ANOVA revealed no significant differences in the constructs between industries. However, there were significant differences between the northern cities (Tianjin and Chong Qing) and southern cities (Guang Zhou, Shanghai and Hong Kong) in some of the dimensions of power and relationship commitment, most likely due to regional differences in cultural, political and economical environment. While regional differences contribute to the variance in the sample, detailed examination of them is beyond the scope of this study.

\subsection{Measurement development}

A rigorous process was used to develop and validate the instrument, modeled on previous empirical studies (Chen and Paulraj, 2004; Garver and Mentzer, 1999; Min and Mentzer, 2004). Prior to data collection, content validity was supported by previous literature, executive interviews and pilot tests. After data collection, we performed a series of analyses to test the reliability and validity of the constructs.

\subsubsection{Unidimensionality and reliability}

A strict process for scale development was employed, particularly since the scales were being used in a very different national culture than the Western culture in which they were developed. We followed the two-step method used in Narasimhan and Jayaram (1998) to test construct reliability, first employing exploratory factor analysis (EFA) to ensure unidimensionality of the scales, then Cronbach's alpha for assessing reliability. EFA was used with principal components analysis for data reduction and determining the main constructs measured by the items. Varimax rotation with Kaiser normalization was used to clarify the factors (Loehlin, 1998). Some measurement items were dropped after comparing their loading on the construct that they were intended to measure to their loadings on other constructs. Cronbach's alpha was then computed for each construct, to test for internal consistency. Using the intercorrelation matrix, items with a correlation value below the 0.30 cutoff value were discarded (Flynn et al., 1994). These steps were performed iteratively.

Because few studies about power have been conducted in China, we investigated the dimensionality of the power construct. EFA was conducted without specifying the number of factors. The Eigenvalues for the first four factors were above 1.0, and the Eigenvalue for the fifth factor was slightly lower than 1.0, thus, four or five factors could be extracted to represent the power construct, which was supported by a scree plot. The four-factor results were somewhat confusing because the reward power items were split, with two loading on the same factor as the items for legitimate power and the other two loading on the same factor as the items for coercive power, making them difficult conceptually explain. Thus, the four-factor solution was discarded. The five-factor solution was retained, and the results were consistent with the five dimensions of power identified in the literature (Table 4). Confirmatory factor analysis (CFA) was used to further justify the factor structure. The model fit indices were $\chi^{2}(142)=499.27$, RMSEA $=0.061, \mathrm{NNFI}=0.97, \mathrm{CFI}=0.98$ and stan dardized $\mathrm{RMR}=0.052$, indicating that the model was acceptable. These fit indices were better than those for four-factor solution, providing further support that five dimensions provide a good conceptualization of customer power in China.

Because literature commonly divides power into mediated and non-mediated sources, we tested a twofactor solution using EFA. The factor loadings were difficult to interpret, with the reward power items split between both factors. We also conducted CFA according to the mediated and non-mediated dichotomy. The fit indices indicated that this model was not acceptable, with NNFI $=0.86$ and CFI $=0.88$. Thus, we did not find evidence to collapse the five dimensions into the two dimensions often used in the Western literature.

The final results of the factor analysis are shown in Tables 4 and 5. The measurement items all had strong 
Table 4

Factor analysis of power

\begin{tabular}{|c|c|c|c|c|c|}
\hline & \multicolumn{5}{|l|}{ Factor loadings } \\
\hline & Coercive power & Legitimate power & Expert power & Referent power & Reward power \\
\hline COE2 & 0.901 & 0.096 & 0.012 & 0.070 & 0.125 \\
\hline COE4 & 0.870 & 0.106 & 0.019 & 0.059 & 0.143 \\
\hline COE3 & 0.862 & 0.142 & 0.043 & 0.024 & 0.227 \\
\hline COE1 & 0.827 & 0.087 & -0.044 & 0.073 & 0.204 \\
\hline LEG1 & 0.076 & 0.777 & 0.238 & 0.136 & 0.112 \\
\hline LEG2 & 0.118 & 0.773 & 0.115 & 0.184 & 0.145 \\
\hline LEG3 & 0.107 & 0.725 & 0.215 & 0.155 & 0.158 \\
\hline LEG4 & 0.117 & 0.697 & 0.118 & 0.046 & 0.367 \\
\hline EXP2 & 0.019 & 0.099 & 0.806 & 0.196 & 0.169 \\
\hline EXP1 & -0.026 & 0.177 & 0.787 & 0.104 & 0.126 \\
\hline EXP3 & -0.102 & 0.119 & 0.777 & 0.271 & 0.102 \\
\hline EXP4 & 0.160 & 0.301 & 0.616 & 0.164 & 0.088 \\
\hline REF2 & 0.099 & 0.162 & 0.199 & 0.858 & 0.166 \\
\hline REF1 & 0.062 & 0.135 & 0.248 & 0.826 & 0.153 \\
\hline REF3 & 0.067 & 0.204 & 0.241 & 0.799 & 0.159 \\
\hline REW2 & 0.212 & 0.290 & 0.161 & 0.151 & 0.767 \\
\hline REW3 & 0.186 & 0.261 & 0.277 & 0.158 & 0.738 \\
\hline REW4 & 0.347 & 0.081 & 0.161 & 0.220 & 0.645 \\
\hline REW1 & 0.308 & 0.439 & 0.018 & 0.159 & 0.589 \\
\hline Eigenvalue & 3.389 & 2.843 & 2.675 & 2.420 & 2.357 \\
\hline Total variance explained & & & $72.018 \%$ & & \\
\hline
\end{tabular}

loadings on the construct that they were supposed to measure and lower loadings on the constructs that they were not supposed to measure, indicating unidimensionality. The Cronbach's alpha values were all above 0.80 (Table 6), except instrumental relationship commitment, which had an alpha value of 0.67 . This was above the lower limit of 0.60 suggested by Flynn et al. (1990) and Nunnally (1994) for newly developed scales. Although this scale had been used in Western countries previously (Brown et al., 1995), it is a new scale in China. Thus, we applied the criterion for newly developed scales.

\subsubsection{Construct validity}

We constructed a CFA model to assess convergent and divergent validity (O'Leary-Kelly and Vokurka, 1998). Each item was linked to its corresponding construct, with the covariances freely estimated. The model fit indices were $\chi^{2}=2558.80$ with d.f. $=674$, RMSEA $=0.070$, NNFI $=0.94, \mathrm{CFI}=0.95$ and standardized RMR $=0.059$, indicating that the model was acceptable (Hu et al., 1992). All factor loadings were greater than 0.50 and all $t$-values were greater than 2.0 (Chau, 1997; Fornell and Larcker, 1981), therefore, convergent validity was demonstrated. To assess discriminant validity, we built a constrained CFA model in which the correlation between each possible pair of constructs were fixed to 1 . This was compared with the original unconstrained model, in which the correlations were freely estimated. Only two differences of $\chi^{2}$ were insignificant at the 0.001 level, therefore, discriminant validity was demonstrated.

\subsection{Structural equation modeling and results}

We used structural equation modeling (SEM) to estimate the causal relationship among the constructs. A two-step model building approach was used, with the measurement models tested prior to testing the structural model (Anderson and Gerbing, 1988; Joreskog and Sorbom, 1993). The maximum likelihood estimation (MLE) method was used because it has desirable asymptotic properties (e.g., minimum variance and unbiasedness) and is scale-free. Multivariate normality (Raykov and Marcoulides, 2000) was verified using univariate $\mathrm{Q}-\mathrm{Q}$ plots. The structural model was built on the modified measurement model using the MLE method. The goodness of fit indices were $\chi^{2}=2622.14$ with d.f. $=680$, RMSEA $=$ $0.071, \mathrm{NNFI}=0.94, \mathrm{CFI}=0.95$, and standardized $\mathrm{RMR}=0.068$, which are better than the threshold values suggested by $\mathrm{Hu}$ et al. (1992). Therefore, our model can be accepted. Fig. 3 shows the structural equation model and the standardized coefficients for 
Table 5

Factor analysis of relationship commitment and customer integration

\begin{tabular}{|c|c|c|c|}
\hline & \multicolumn{3}{|l|}{ Factor loadings } \\
\hline & Customer integration & Normative relationship commitment & Instrumental relationship commitment \\
\hline CI10 & 0.769 & 0.072 & 0.057 \\
\hline CI3 & 0.757 & 0.101 & -0.008 \\
\hline CI11 & 0.756 & 0.133 & 0.086 \\
\hline CI8 & 0.747 & 0.109 & 0.155 \\
\hline CI9 & 0.733 & 0.204 & 0.168 \\
\hline CI4 & 0.677 & 0.254 & -0.058 \\
\hline CI5 & 0.667 & 0.199 & -0.106 \\
\hline $\mathrm{CI} 7$ & 0.666 & 0.219 & -0.030 \\
\hline CI6 & 0.639 & 0.144 & -0.091 \\
\hline CI2 & 0.636 & 0.020 & -0.112 \\
\hline CI1 & 0.633 & 0.011 & -0.126 \\
\hline NRC4 & 0.147 & 0.849 & 0.161 \\
\hline NRC5 & 0.131 & 0.845 & 0.146 \\
\hline NRC3 & 0.147 & 0.814 & 0.115 \\
\hline NRC6 & 0.182 & 0.764 & 0.210 \\
\hline NRC1 & 0.156 & 0.745 & -0.057 \\
\hline NRC2 & 0.148 & 0.718 & -0.063 \\
\hline IRC2 & 0.035 & 0.159 & 0.824 \\
\hline IRC1 & -0.133 & -0.026 & 0.788 \\
\hline IRC3 & 0.007 & 0.150 & 0.629 \\
\hline Eigenvalue & 5.551 & 4.061 & 1.921 \\
\hline Total variance explained & & $57.666 \%$ & \\
\hline
\end{tabular}

Table 6

Reliability analysis

\begin{tabular}{lcl}
\hline Construct & $\begin{array}{l}\text { No. of } \\
\text { items }\end{array}$ & $\begin{array}{l}\text { Cronbach's } \\
\text { alpha }\end{array}$ \\
\hline Expert power & 4 & 0.813 \\
Referent power & 3 & 0.875 \\
Legitimate power & 4 & 0.825 \\
Reward power & 4 & 0.831 \\
Coercive power & 4 & 0.915 \\
Normative relationship commitment & 6 & 0.897 \\
Instrumental relationship commitment & 3 & 0.667 \\
Customer integration & 11 & 0.900 \\
\hline
\end{tabular}

the paths that were significant at the 0.05 level. The results of hypotheses tests are presented in Table 7.

\section{Discussion and managerial implications}

\subsection{Power-relationship commitment theory in China}

Our findings provide insight into the mechanisms of power-relationship commitment theory in China from a SC perspective. Fig. 3 reveals that expert and referent power had a positive impact on normative relationship commitment, indicating that customers' use of non- mediated power enhanced the manufacturer's commitment, supporting $\mathrm{H} 1 \mathrm{a}$, and H1b. The influence of legitimate power on normative relationship commitment was insignificant, and $\mathrm{H} 3 \mathrm{c}$ was not supported. Expert, referent and legitimate power had no impact on instrumental relationship commitment, which does not support the hypothesized negative relationship between non-mediated sources of power and instrumental relationship commitment; however, this is consistent with Brown et al.'s (1995) findings.

These findings provide insight into power-relationship commitment theory in China. Expert and referent power were related to normative relationship commitment, but not to instrumental relationship commitment. In other words, although the expert and referent power of customers enhances manufacturers' commitment normatively, they do not choose to exercise it in an instrumental way. When a manufacturer accepts its customer's influence because of the customer's specialized knowledge and expertise or good reputation, it learns from the customer. This fosters identification with and internalization of the customer's values and norms, enhancing normative relationship commitment, but does not significantly influence instrumental relationship commitment. The impact of expert power on normative relationship commitment indicates that 


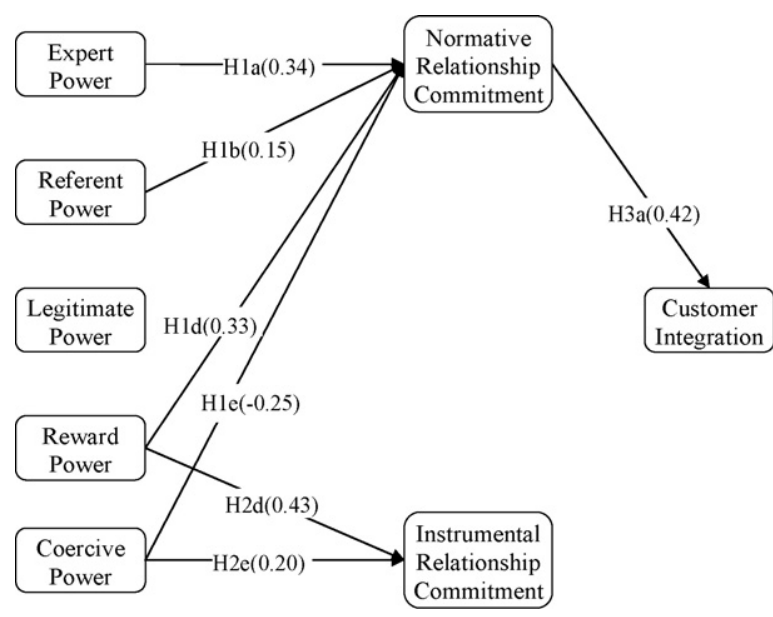

Fig. 3. Structural equation model.

Chinese managers have a strong belief in knowledge and authority, combined with a powerful desire to learn.

Legitimate power was not significantly related to either type of relationship commitment. There are several potential explanations for this. First, the customer's natural right to influence a manufacturer is universally accepted in China, so this source of power is not related to any unique characteristic of the customer. Although legitimate power is strong, it is pervasive and does not particularly influence relationship commitment. Second, China's collective culture, combined with the existence of guanxi networks, causes the power base to shift from natural rights of the customer to in-group versus out-group differences in the extended network. Customers are not perceived as having power by natural right; rather, the perception of power derives from whether the customer is in the ingroup in the extended guanxi network. The influence of a customer, merely by virtue of being a customer, is not significant.

The path coefficients in Fig. 3 show that customers' reward power had a relatively high impact on both normative and instrumental relationship commitment; thus H1d was not supported, but $\mathrm{H} 2 \mathrm{~d}$ was. Coercive power had a positive impact on instrumental relationship commitment, but a negative impact on normative relationship commitment, thus supporting both H1e and $\mathrm{H} 2 \mathrm{e}$. As predicted, coercion plays a significant role in instrumental relationship commitment, but is associated with lower levels of normative relationship commitment.

It is interesting that coercive power had a negative impact on normative relationship commitment, while

Table 7

Results of hypothesis tests

Hypothesis

H1a: A supplier's normative relationship commitment will be positively related to its perception of the expert power of its customer

H1b: A supplier's normative relationship commitment will be positively related to its perception of the referent power of its customer

H1c: A supplier's normative relationship commitment will be positively related to its perception of the legitimate power of its customer

H1d: A supplier's normative relationship commitment will be negatively related to its perception of the reward power of its customer

H1e: A supplier's normative relationship commitment will be negatively related to its perception of the coercive power of its customer

H2a: A supplier's instrumental relationship commitment will be negatively related to its perception of the expert power of its customer

H2a: A supplier's instrumental relationship commitment will be negatively related to its perception of the referent power of its customer

H2a: A supplier's instrumental relationship commitment will be negatively related to its perception of the legitimate power of its customer

H2a: A supplier's instrumental relationship commitment will be positively related to its perception of the reward power of its customer

H2a: A supplier's instrumental relationship commitment will be positively related to its perception of the coercive power of its customer

H3a: The degree of integration between a supplier and a customer will be positively related to the supplier's normative relationship commitment

H3b: The degree of integration between a supplier and a customer will be negatively related to the supplier's instrumental relationship commitment

H3c: Normative relationship commitment by the supplier will have a stronger impact on customer integration than instrumental relationship commitment

Outcome

Supported

Supported

Rejected

Rejected

Supported

Rejected

Rejected

Rejected

Supported

Supported

Supported

Rejected

Supported 
reward power had a positive impact on it, since both reward and coercive power are classified as "mediated" sources of power in the Western literature (Brown et al., 1995). This may reflect the Chinese tendency to use positive feedback to encourage others to commit to their values and norms, while using negative feedback to regulate and manage calculative relationships. The positive relationship between reward power and normative relationship commitment contradicts Brown et al.'s (1995) findings, which may be due to cultural differences (Hofstede, 1983, 1984). In the Chinese high power distance culture, as in the West, reward power brings the instrumental relationship commitment of the partners. However, it also improves normative relationship commitment. Due to the existence of guanxi in business relationships, manufacturers expect preferential treatment from customers in exchange for favors and obligations (Lee et al., 2001). Because reciprocation of a favor as soon as the opportunity arises is a morally binding social norm (Lee and Dawes, 2005), not returning a favor results in loss of face for both the manager and his in-group. Therefore, if the customer does not reward the manufacturer for the good performance or favors it delivered, the customer's trust and normative relationship commitment will decrease. In contrast, when the customer uses reward power to meet the manufacturer's expectation of reciprocity, normative relationship commitment is further enhanced. Therefore, reward power plays a very different role in Chinese culture, compared with Western cultures. This was supported by our exploratory analysis of the two factor solution, which where the loadings for reward power were split between the factors for mediated and nonmediated power. Understanding the role of reward power in China further develops power-relationship commitment theory. To confirm our findings, future cross-cultural studies should be carried out to further explore configural and structural differences in the relationship between power and relationship commitment in a SC context.

Understanding the development of power-relationship commitment in China is helpful for practitioners in selecting strategies for dealing with their SC partners. Because expert power was the most important in improving normative relationship commitment, customers should strive to hire knowledgeable people and manage their expertise and skills. Referent power was the next most important. Customers should refrain from the use of coercive power, because it enhances the manufacturer's instrumental relationship commitment, while reducing its normative relationship commitment. Reward power should be used cautiously because it may lead to different outcomes in China. SC partners should develop an understanding of the effect of different types of power, and should selectively exercise their power, in order to enhance relationship commitment.

\subsection{The effect of relationship commitment on SCI}

This study also investigated the link between powerrelationship commitment theory and customer integration in Chinese supply chains. The path coefficients in Fig. 3 show that normative relationship commitment had a very strong positive impact on CI, supporting $\mathrm{H} 3 \mathrm{a}$. However, the coefficient for the path from instrumental relationship commitment to $\mathrm{CI}$ was not significant and did not support H3b. This is consistent with Gounaris' (2005) finding that instrumental relationship had no impact on customer retention or investment intention. Comparing the equal coefficients constrained model with the unconstrained model, we found that the two coefficients were significantly different from each other, indicating support for $\mathrm{H} 3 \mathrm{c}$. However, there was a significant difference between normative and instrumental relationship commitment in enhancing CI. Since integration requires transaction-specific asset investment, partners should strive for a longer-term orientation, as well as congruence in their values, norms of behavior and managerial approaches.

Manufacturers should cultivate normative relationship commitment with their customers, in order to enhance integration. Committed customers cooperate with manufacturers, sharing information and integrating inter-organizational processes. When partners have an intrinsic desire to continue a relationship due to congruence in values and norms, CI can be achieved more readily. In contrast, instrumental relationship commitment does not have any significant influence on $\mathrm{CI}$, due to its short-term and loose nature. Therefore, manufacturers should refrain from cultivating instrumental relationship commitment because it has no effect on CI and may actually damage shared values and norms in the long term.

\section{Conclusions and limitations}

We have provided a holistic perspective of customer integration by employing both transaction cost theory and social exchange theory, and investigated the impact of power and relationship commitment on CI, using power-relationship commitment theory. Our study is the first to study these relationships using data collected from manufacturers in China. Because of China's rapidly growing manufacturing base and unique 
national culture, our findings provide fruitful managerial implications for both SC practitioners and researchers.

This study makes a significant contribution to the SCM and relationship management literature by systematically examining the influence of power on relationship commitment in a SC context. Overall, the results show that appropriate use of power can significantly enhance relationship commitment. Improvement in relationship commitment, especially normative relationship commitment, improves $\mathrm{CI}$, while reducing transaction costs and opportunistic behaviors.

This study shows that power and relationship commitment are especially important for CI, due to China's collective and high power distance culture and the existence of guanxi networks in SC relationships. Some of the relationships between power and relationship commitment in China are different from those reported by Brown et al.'s (1995) U.S.-based study. While Brown et al. (1995) reported that mediated power had a negative impact on normative relationship commitment, we found that reward power had a positive impact on both normative and instrumental relationship commitment in China. We speculate that these differences might be caused by the differences in national culture between China and the U.S. This study justifies and extends power-relationship commitment theory, established in Western marketing channel literature, to Chinese culture and supply chain management.

These findings provide guidelines for managers in developing power in SC relationships. Our model demonstrates that normative relationship commitment is strongly related to $\mathrm{CI}$, clearly showing the importance of managing SC relationships. Thus, this study establishes a link between power-relationship commitment theory and SCI.

Although this study makes significant contributions to both academia and practice, there are several limitations which open up venues for further research. First, besides power and relationship commitment, many other factors, such as competitive hostility, environmental uncertainty and other inter-organizational relationships (e.g. transaction-specific assets, dependence, trust), may also influence $\mathrm{CI}$ and relationship commitment. Future studies should seek additional drivers of CI and examine their impact. Second, the impact of industry and region were not explicitly investigated in this study. In some industries or regions, the relationship between power, relationship commitment and SC integration may be different, due to differences in customer requirements and preferences.
Third, we only used data from China to develop and test the model. Although instrumental relationship commitment had an acceptable Cronbach's alpha, it was relatively low. Future studies should further develop this construct, to provide a deeper understanding of it in China. Because culture may have a significant influence on the conceptualization of power and relationship commitment and their interrelationship, future studies should examine configural and structural differences in these constructs and their relationship in different cultures. Fourth, we examined the relationship between manufacturers and their primary customers. We did not examine the types of customer companies (retailers, distributors, manufacturers) and their power position relative to the manufacturers, which provides another opportunity for future research. Furthermore, this study only examined sources of customer power from the perspective of the manufacturer. Future studies should collect the perspectives of both manufacturers and customers, which may shed new light on the relationship between power and relationship commitment. Finally, this study only examined dyadic relationships between manufacturers and their customers. To understand the entire SC, future studies should examine power and relationship commitment among suppliers, manufacturers and customers together. Examination of triadic relationships will reveal more complex dynamic relationships among them.

\section{Acknowledgement}

This research was supported by the Center for Supply Chain Management \& Logistics, Li \& Fung Institute of Supply Chain Management and Logistics.

\section{Appendix A. Construct measurement}

\section{A.1. Customer integration (selected from Narasimhan and Kim, 2002; Frohlich and Westbrook, 2001)}

Please indicate the extent of integration or information sharing between your organization and your major customer in the following areas $(1=$ not at all; $7=$ extensive).

- CI1: The level of linkage with major customer through information network.

- CI2: The level of computerization for our major customer ordering. 
- CI3: The level of sharing of market information from our major customer.

- CI4: The level of communication with our major customer.

- CI5: The establishment of quick ordering system with our major customer.

- CI6: Follow-up with our major customer for feedback.

- CI7: The frequency of periodical contacts with our major customer.

- CI8: Our major customer shares point of sales (POS) information with us.

- CI9: Our major customer shares demand forecast with us.

- CI10: We share our available inventory with our major customer.

- CI11: We share our production plan with our major customer.

\section{A.2. Relationship commitment (adapted from}

Brown et al., 1995)

The following statements are about you and your major customer concerning relationship. Please indicate the degree of agreement that you have with each statement. $(1=$ strongly disagree; $7=$ strongly agree $)$.

\section{A.2.1. Normative relationship commitment}

- NRC1: We feel that our major customer views us as being an important "team members," rather than our being just another supplier.

- NRC2: We are proud to tell others that we are a supplier for this customer.

- NRC3: Our attachment to this customer is primarily based on the similarity of our values and those of this customer.

- NRC4: The reason we prefer this customer to others is because of what it stands for, its values.

- NRC5: During the past year, our company's values and those of the major customer have become more similar.

- NRC6: What this customer stands for is important to our company.

\section{A.2.2. Instrumental relationship commitment}

- IRC1: Unless we are rewarded for it in some way, we see no reason to expend extra effort on behalf of this customer.

- IRC2: How hard we work for this major customer is directly linked to how much we are rewarded.

- IRC3: Bargaining is necessary in order to obtain favorable terms of SC in dealing with this customer.

\section{A.3. Power (adapted from Brown et al., 1995)}

The following statements are about you and your major customer concerning power. Please indicate the degree of agreement that you have with each statement $(1=$ strongly disagree; 7 = strongly agree $)$.

\section{A.3.1. Expert power}

- EXP1: The people in the customer's organization knew what they are doing.

- EXP2: We usually got good advice from our major customer.

- EXP3: The customer had specially trained people who really knew what had to be done.

- EXP4: Our major customer's business expertise made them likely to suggest the proper thing to do.

\section{A.3.2. Referent power}

- REF1: We really admire the way our major customer runs their business, so we tried to follow their lead.

- REF2: We generally wanted to operate our company very similar to the way we thought the major customer would.

- REF3: Our company did what the customer wanted because we have very similar feelings about the way a business should be run.

\section{A.3.3. Legitimate power}

- LEG1: It was our duty to do as the major customer requested.

- LEG2: We had an obligation to do what the major customer wanted, even though it wasn't a part of the contract.

- LEG3: Since they were the customer, we accepted their recommendations.

- LEG4: The major customer had the right to expect us to go along with their request.

\section{A.3.4. Reward power}

- REW1: If we did not do what as the major customer asked, we would not have received very good treatment from them.

- REW2: We felt that by going along with the major customer, we would have been favored on some other occasions.

- REW3: By going along with the major customer's requests, we avoided some of the problems other suppliers face.

- REW4: Our major customer often rewarded us to get our company to go along with their wishes. 


\section{A.3.5. Coercive power}

- COE1: The major customer's personnel would somehow get back at us if we did not do as they asked and they would have found out.

- COE2: The major customer often hinted that they would take certain actions that would reduce our profits if we did not go along with their requests.

- COE3: The major customer might have withdrawn certain needed services from us if we did not go along with them.

- COE4: If our company did not agree to their suggestions, the major customer could have made things more difficult for us.

\section{References}

Ahmad, S., Schroeder, R.G., 2001. The impact of electronic data interchange on delivery performance. Production and Operations Management 10 (1), 16-30.

Anderson, E., Weitz, B., 1992. The use of pledge to build and sustain commitment in distribution channels. Journal of Marketing Research 29 (1), 18-34.

Anderson, J.C., Narus, J.A., 1990. A model of distributor firm and manufacturing firm working partnerships. Journal of Marketing 54 (1), 42-58.

Anderson, J.C., Gerbing, D.W., 1988. Structural equation modeling in practice: a review and recommended two-step approach. Psychological Bulletin 103 (3), 411-423.

Armistead, C.G., Mapes, J., 1993. The impact of supply chain integration on operating performance. Logistics Information Management 6 (4), 9-14.

Atuahene-Gima, K., Li, H., 2002. When does trust matter? Antecedents and contingent effects of supervisee trust on performance in selling new products in China and the United States. Journal of Marketing 66 (3), 61-81.

Benton, W.C., Maloni, M., 2005. The influence of power driven buyer/ seller relationships on supply chain satisfaction. Journal of Operations Management 23 (1), 1-22.

Blau, P., 1964. Exchange and Power in Social Life. Wiley, New York.

Bowersox, D.J., Closs, D.J., Stank, T.P., 1999. 21st Century Logistics: Making Supply Chain Integration a Reality. Council of Logistics Management, Oak Brook, IL.

Bowersox, D.J., Morash, E.A., 1989. The integration of marketing flows in channels of distribution. European Journal of Marketing 23 (20), 58-67.

Boyer, K.K., Lewis, M.W., 2002. Competitive priorities: investigating the need for supply chain trade-offs in operations strategy. Journal of Operations Management 11 (1), 9-20.

Briley, D.A., Wyer, R.S., 2002. The effect of group membership salience on the avoidance of negative outcomes: implications for social and consumer decisions. Journal of Consumer Research 29 (3), 400-415.

Brown, J.R., Lusch, R.F., Muehling, D.D., 1983. Conflicts and powerdependence relations in retailer-supplier channels. Journal of Retailing 59 (4), 53-80.

Brown, J.R., Lusch, R.F., Nicholson, C.Y., 1995. Power and relationship commitment: their impact on marketing channel member performance. Journal of Retailing 71 (4), 363-392.
Carr, A.S., Pearson, J.N., 1999. Strategically managed buyer-supplier relationships and performance outcomes. Journal of Operations Management 17 (5), 497-519.

Chau, P.Y.K., 1997. Reexamining a model for evaluating information center success using a structural equation modeling approach. Decision Sciences 28 (2), 309-334.

Chen, I.J., Paulraj, A., 2004. Understanding supply chain management: critical research and a theoretical framework. International Journal of Production Research 42 (1), 131-163.

Chow, C.W., Deng, F.J., Ho, J.L., 2000. The openness of knowledge sharing within organizations: a comparative study of the United States and the People's Republic of China. Journal of Management Accounting Research 12 (1), 65-95.

Coase, R.H., 1937. The nature of the firm. Economica, N.S. 4 (3), 386405.

Drea, J.T., Bruner, G.C., Hensel, P.J., 1993. Comparing alternative measures of the French and Raven power bases. Journal of Personal Selling and Sales Management 13 (4), 73-80.

Dwyer, F.R., Schurr, P.H., Oh, S., 1987. Developing buyer-seller relationships. Journal of Marketing 51 (2), 11-27.

Eaton, L., Louw, J., 2000. Culture and self in South Africa: individualism-collectivism predictions. Journal of Social Psychology 140 (2), 210-217.

Ellram, L.M., 1991. A managerial guideline for the development and implementation of purchasing partnerships. International Journal of Purchasing and Materials Management 27 (3), 2-8.

Etzioni, A., 1975. Comparative Analysis of Complex Organizations. MacMillan Publishing Co., New York.

Flynn, B.B., Flynn, E.J., 2004. An exploratory study of the nature of cumulative capabilities. Journal of Operations Management 22 (5), 439-458.

Flynn, B.B., Sakakibara, S., Schroeder, R.G., Bates, K.A., Flynn, E.J., 1990. Empirical research methods in operations management. Journal of Operations Management 9 (2), 250-273.

Flynn, B.B., Schroeder, R.G., Sakakibara, S., 1994. A framework for quality management research and an associated measurement instrument. Journal of Operations Management 11 (4), 339575.

Fornell, C., Larcker, D.F., 1981. Evaluating structural equation models with unobservable variables and measurement error. Journal of Marketing Research 18 (1), 29-50.

Fournier, S., 1998. Consumers and their brands: developing relationship marketing in consumer research. Journal of Consumer Research 24 (2), 343-374.

Frazier, G.L., Summers, J.O., 1986. Perceptions of inter-firm power and its use within a franchise channel. Journal of Marketing Research 23 (5), 169-176.

French, R.P., Raven, B.H., 1959. The bases of social power. In: Cartwright, D. (Ed.), Studies in Social Power. University of Michigan Press, Ann Arbor, MI, pp. 155-164.

Frohlich, M.T., Westbrook, R., 2001. Arcs of integration: an international study of supply chain strategies. Journal of Operations Management 19 (2), 185-200.

Garver, M., Mentzer, J.T., 1999. Logistics research methods: employing structural equation modeling to test for construct validity. Journal of Business Logistics 20 (1), 33-58.

Geyskens, I., Steenkamp, J.E.M., Kumar, N., 1999. A meta-analysis of satisfaction in marketing channel relationships. Journal Marketing Research 36 (2), 223-238.

Ghoshal, S., Moran, P., 1996. Bad for practice: a critique of the transaction cost theory. Academy of Management Review 21 (1), 13-47. 
Goodman, L.E., Dion, P.A., 2001. The determinants of commitment in the distributor-supplier relationship. Industrial Marketing Management 30 (3), 287-300.

Gounaris, S.P., 2005. Trust and commitment influences on customer retention: insights from business-to-business services. Journal of Business Research 58 (2), 126-140.

Granovetter, M., 1985. Economic action and social structure: the problem of embeddedness. American Journal of Sociology 91 (3), 481-510.

Griffith, D.A., Myers, M.B., Harvey, M.G., 2006. An investigation of national culture's influence on relationships and knowledge relationships in interorganizational relationships between Japan and the United States. Journal of International Marketing 14 (3), $1-32$.

Gundlach, G.T., Archrol, R.S., Mentzer, J.T., 1995. The structure of commitment in exchange. Journal of Marketing 59 (1), 78-92.

Heide, J.B., 1994. Interorganizational governance in marketing channels. Journal of Marketing 58 (1), 71-85.

Hess, J., Story, J., 2005. Trust-based commitment: multidimensional consumer-brand relationships. Journal of Consumer Marketing 22 (6), 313-322.

Hill, C.W.L., 1990. Cooperation, opportunism and the invisible hand: implications for transaction cost theory. Academy of Management Review 15 (3), 500-513.

Hochwarter, W.A., James, M., Johnson, D., Ferris, F.R., 2004. The interactive effects of politics, perceptions and trait cynicism on work outcomes. Journal of Leadership and Organizational Studies 10 (4), 44-57.

Hofstede, G., 1980. Culture's Consequences: International Differences in Work-related Values. Sage Publications, Beverly Hills, CA.

Hofstede, G., 1983. The cultural relativity of organizational practices and theories. Journal of International Business Studies 14 (2), $75-89$.

Hofstede, G., 1984. Culture's consequence: International differences in work-related values. Sage, Newbury.

Hofstede, G., 1991. Cultures and Organizations: Software of the Mind. McGraw-Hill, London.

Hofstede, G., Van Deusen, C.A., Mueller, C.B., Charles, T.A., 2002. What goals do business leaders pursue? A study in fifteen countries. Journal of International Business Studies 33 (4), 785-803.

Hu, L., Bentler, P.M., Kano, Y., 1992. Can test statistics in covariance structure analysis be trusted? Psychological Bulletin 112 (2), 351362.

Jap, S.D., Ganesan, S., 2000. Control mechanisms and the relationship life cycle: implications for safeguarding specific investments and developing commitment. Journal of Marketing Research 37 (2), $227-245$

Johnson, J.L., 1999. Strategic integration in industrial distribution channels: managing the interfirm relationship as a strategic asset. Journal of Academy of Marketing Sciences 27 (1), 4-18.

Jonsson, P., Ziveldin, M., 2003. Achieving high satisfaction in supplier dealer working relationships. Supply Chain Management: An International Journal 8 (3), 224-240.

Joreskog, K., Sorbom, D., 1993. LISREL 8: Structural Equation Modeling with the Simples Command Language. Lawrence Erlbaum Associates, Hillsdale, NJ.

Joshi, A.W., Stump, R.L., 1999. Determinants of commitment and opportunism: Integrating insights from transaction cost analysis and relational exchange theory. Canadian Journal of Administrative Sciences 16 (4), 334-352.
Kasulis, J.J., Spekman, R.E., 1980. A framework for the use of power. European Journal of Marketing 14 (4), 180-191.

Kumar, N., Scheer, L.K., Steenkamp, J.B.E.M., 1995. The effects of perceived interdependence on dealer attitudes. Harvard Business Review 74 (6), 92-106.

Kumar, N., Scheer, L.K., Steenkamp, J.E.M., 1998. Interdependence, punitive capacity and the reciprocation of punitive actions in channel relationships. Journal of Marketing Research 35 (2), 225-235.

LaLonde, B.J., Cooper, M.C., 1989. Partnerships in Providing Customer Service: A Third Party Perspective. Council of Logistics Management, Oakbrook, IL.

Lawler, E.J., 1986. Bilateral deterrence and conflict spiral: a theoretical analysis. In: Lawler, E.J. (Ed.), Advances in Group Processes, vol. 3. JAI Press, pp. 107-130.

Lawler, E.J., Ford, R.S., Blegen, M.A., 1988. Coercive capability in conflict: a test of bilateral deterrence versus conflict spiral theory. Social Psychology Quarterly 51 (2), 93-107.

Lee, H.L., Billington, C., 1992. Managing supply chain inventory: pitfalls and opportunities. Sloan Management Review 33 (3) 65-73.

Lee, D.Y., Dawes, P.L., 2005. Guanxi, trust and long-term orientation in Chinese business markets. Journal of International Marketing 13 (2), 20-56

Lee, D.L., Pae, J.H., Wong, Y.H., 2001. A model of close business relationships in China (guanxi). European Journal of Marketing 35 $(1 / 2), 51$.

Leung, T.K.P., Lai, K.H., Chan, R.Y.K., Wong, Y.H., 2005. The roles of xinyong and guanxi in Chinese relationship marketing. European Journal of Marketing 39 (5), 528-559.

Loehlin, J.C., 1998. Latent Variable Models. Lawrence Erlbaum, Hillsdale, NJ

Maloni, M., Benton, W.C., 2000. Power influences in the supply chain. Journal of Business Logistics 21 (1), 49-73.

Min, S., Mentzer, J.T., 2004. Developing and measuring supply chain management concepts. Journal of Business Logistics 25 (1), 63-99.

Moore, K.R., 1998. Trust and relationship commitment in logistics alliances: a buyer perspective. International Journal of Purchasing and Materials Management 34 (2), 211-237.

Morash, E.A., Clinton, S.R., 1998. Supply chain integration: customer value through collaborative closeness versus operational excellence. Journal of Marketing Theory and Practice 6 (4), 104-120.

Morgan, R.M., Hunt, S.D., 1994. The commitment-trust theory of relationship marketing. Journal of Marketing 58 (3), 20-38.

Morris, M.H., Calantone, R.J., 1991. Redefining the purchasing function: an entrepreneurial perspective. International Journal of Purchasing and Materials Management 27 (4), 2-9.

Narasimhan, R., Kim, S.W., 2001. Information system utilization strategy for supply chain integration. Journal of Business Logistics $22(2), 51-75$

Narasimhan, R., Kim, S.W., 2002. Effect of supply chain integration on the relationship between diversification and performance: evidence from Japanese and Korean firms. Journal of Operations Management 20 (3), 303-323.

Narasimhan, R., Jayaram, J., 1998. Causal linkages in supply chain management: an exploratory study of North American manufacturing firms. Decision Sciences 29 (3), 579-605.

Naylor, J.B., Naim, M.M., Berry, D., 1999. Leagility: integrating the lean and agile manufacturing paradigms in the total supply chain. International Journal of Production Economics 62 (1/2), 107-118. Nunnally, J., 1994. Psychometric Methods. McGraw-Hill, New York. 
O’Leary-Kelly, S.W., Vokurka, R.J., 1998. The empirical assessment of construct validity. Journal of Operations Management 16 (4), $387-405$.

Pearce, J.L., 2001a. Organization and Management in the Embrace of Government. Lawrence Erlbaum Associates, Mahwah, NJ.

Pearce, J.L., 2001b. How can we learn how governments matter to management and organizations? Journal of Management Inquiry 10 (2), 103-112.

Pfeffer, J., Salancik, G.R., 1978. The External Control of Organizations. Harper and Row, New York.

Podsakoff, P.M., MacKenzie, S.B., Lee, J.Y., Podsakoff, N.P., 2003. Common method bias in behavioral research: a critical review of the literature and recommended remedies. Journal of Applied Psychology 88 (5), 879-903.

Podsakoff, P.M., Organ, D.W., 1986. Self-reports of organizational research: problems and prospects. Journal of Management 12 (4), 531-544.

Power, D., 2005. Supply chain management integration and implementation: a literature review. Supply Chain Management 10 (3/ 4), 252-263.

Rabin, M.A., Antonioni, D., Pseneika, C., 2001. A structural equations model of leader power, subordinate's styles of handling conflict and job performance. The International Journal of Conflict Management 12 (3), 191-211.

Ramaseshan, B., Yip, L.S.C., Pae, J.H., 2006. Power, satisfaction, and. relationship commitment in Chinese store-tenant relationship and their impact on performance. Journal of Retailing 82 (1), 63-70.

Randolph, W.A., Sashkin, M., 2002. Can organizational empowerment work in a multinational setting? Academy of Management Executive 16 (1), 102-115.

Rao, A.N., Pearce, J.J., Xin, K., 2005. Governments, reciprocal exchange and trust among business associates. Journal of International Business Studies 36 (1), 104-118.

Raykov, T., Marcoulides, G.A., 2000. A First Course in Structural Equation Modeling. Lawrence Erlbaum and Associates, New Jersey.

Rezaboklah, B., Bornemann, D., Hansen, U., Schrader, U., 2006. Consumer power: a comparison of the old economy and the Internet economy. Journal of Consumer Policy 29 (1), 3-36.

Rubin, J.Z., Brown, B.F., 1975. The Social Psychology of Bargaining and Negotiation. Academic Press, New York.

Ruyter, K., Moorman, L., Lemmink, J., 2001. Antecedents of commitment and trust in customer-supplier relationships in high technology markets. Industrial Marketing Management 30 (3), 271-286.

Skinner, S.J., Gassenheimer, J.B., Kelley, S.W., 1992. Cooperation in supplier-dealer relationships. Journal of Retailing 66 (3), 315336.

Stank, T.P., Keller, S.B., Closs, D.J., 2001a. Performance benefits of supply chain integration. Transportation Journal 41 (2), 31-46.

Stank, T.P., Keller, S.B., Daughery, P.J., 2001b. Supply chain collaboration and logistical service performance. Journal of Business Logistics 22 (1), 29-48.

Stevens, G.C., 1989. Integrating the supply chain. International Journal of Physical Distribution and Logistics Management 19 (8), 3-8.

Tedeschi, J.T., Schlenker, B.R., Lindskold, S., 1972. The Exercise of Power and Influence: The Source of Influence. The Social Influence Process. Aldine-Atherton, Chicago, pp. 287-375.

Thibaut, J.W., Kelley, H.H., 1959. The Social Psychology of the Group. Wiley, New York.
Vickery, S.K., Jayaram, J., Droge, C., Calantine, R., 2003. The effects of an integrative supply chain strategy on customer service and financial performance: an analysis of direct versus indirect relationships. Journal of Operations Management 21 (5), 523-539.

Wang, K.Y., Clegg, S., 2002. Trust and decision making: are managers different in the People's Republic of China and in Australia? Cross-Cultural Management 9 (1), 30-45.

Watts, C.A., Hahn, C.K., 1993. Supplier development programs: an empirical study. International Journal of Purchasing and Materials Management 29 (2), 11-17.

Watts, C.A., Kim, K.Y., Hahn, C.K., 1995. Linking purchasing to corporate competitive strategy. International Journal of Purchasing and Materials Management 31 (2), 3-8.

Wetzels, M., de Ruyter, K., van Birgelen, M., 1998. Marketing service relationships: the role of commitment. The Journal of Business \& Industrial Marketing 13 (4/5), 406-423.

Williamson, O.E., 1975. Markets and Hierarchies: Economics and Antitrust Implications. The Free Press, New York.

Williamson, O.E., 1985. The Economic Institutions of Capitalism: Firms, Markets, Relational Contracting. The Free Press, New York.

Williamson, O., 1991. Strategizing, economizing and economics organization. Strategic Management Journal 12 (8), 75-94.

Williamson, O.E., 1993. Calculativeness, trust, and economic organization. Journal of Law and Economics 36 (4), 453-486.

Williamson, O.E., 1996. The Mechanisms of Governance. The Free Press, New York.

Wisner, J.D., Tan, K.C., 2000. Supply chain management and its impact on purchasing. Journal of Supply Chain Management 36 (4), 33-42.

Wong, A.S.H., Tjosvold, D., Zhang, P., 2005. Supply chain relationships for customer satisfaction in China: leadership, interdependence, and cooperative goals. Asia Pacific Journal of Management 22, 179-199.

Wu, W.Y., Chiang, C.-Y., Wu, Y.-J., Tu, H.-J., 2004. The influencing factors of commitment and business integration on supply chain management. Industrial Management and Data System 104 (4), 322-333.

Zaheer, A., Venkataraman, N., 1995. Relational governance as interorganizational strategy: an empirical test of the role of trust in economic exchange. Strategic Management Journal 16 (4), 373392.

Zhao, X., Flynn, B.B., Roth, A.V., 2006a. Decision sciences research in China: a critical review and research agenda-foundations and overview. Decision Sciences 37 (4), 451-496.

Zhao, X., Nie, W., Huo, B., Yeung, J., 2006b. The impact of supply chain integration on company performance and supply chain performance in China. Working Paper. The Chinese University of Hong Kong, Hong Kong.

Zhuang, G., Zhou, N., 2004. The relationship between power and dependence in marketing channels: a Chinese perspective. European Journal of Marketing 38 (5/6), 675-693.

Dr. Xiande Zhao is Professor of Operations Management in the Department of Decision Sciences and Managerial Economics and Director of the Center for Supply Chain Management and Logistics, Li \& Fung Institute of Supply Chain Management and Logistics, The Chinese University of Hong Kong. He received his Ph.D. in Business Administration and MBA from the University of Utah, USA. Prof. Zhao's teaching and research interests are in the areas of supply chain management and service operations management. He has published over fifty articles in refereed journals including the Journal of 
Operations Management, Journal of Consumer Research, Decision Sciences, European Journal of Operations Research, International Journal of Production Research, and other journals.

Dr. Baofeng Huo is an assistant professor of operations management at the School of Management at Xi'an Jiaotong University and a Research Fellow at Center for Supply Chain Management \& Logistics, Li \& Fung Institute of Supply Chain Management and Logistics, The Chinese University of Hong Kong. He received a $\mathrm{Ph} . \mathrm{D}$. in operations management from The Chinese University of Hong Kong, a B.E. in management information system and a M.E. in management science and engineering from Tianjin University. His research interests are logistics and supply chain management.

Dr. Barbara B. Flynn is the Richard M. and Myra Louise Buskirk Professor of Manufacturing Management and Director of the Indiana University Center for International Business Education and Research (CIBER) at the Kelley School of Business at Indiana University. She received her D.B.A. in operations management from Indiana University and her M.B.A. from Marquette University. She is a Fellow of the Decision Sciences Institute and recipient of the Distinguished Scholar Award from the Operations Management division of the Academy of Management. Dr. Flynn has received over \$1 million in research funding from the National Science Foundation, the U.S Department of Education and the Center for Innovation Management Studies. She has published articles in Management Science, Decision Sciences, Journal of Operations Management, International Journal of Operations and Production Management and other leading journals, as well as a book and numerous book chapters. Dr. Flynn is Editor-in-Chief and founding editor of Decision Sciences Journal of Innovative Education, and Editor-in-Chief of Quality Management Journal. She is a past President of the Decision Sciences Institute and has held leadership positions in the Academy of Management and American Society for Quality.

Dr. Jeff Hoi Yan Yeung is a Professional Consultant at The Chinese University of Hong Kong. He teaches supply chain management and E-commerce for the M.Sc. and MBA programs. Dr. Yeung received his M.Sc. in Industrial Engineering from University of Houston, USA and $\mathrm{Ph} . \mathrm{D}$. in Manufacturing Engineering from Queensland University of Technology, Australia. Prior to joining CUHK, Dr. Yeung was a business consultant for J.D. Edwards. His research areas include supply chain management, E-commerce, business process reengineering and operations management. Dr. Yeung has published many articles in reputable journals including International Journal of Production Research, Communications of ACM and Total Quality Management. 